\title{
The Use of Functional Opportunities of Virtual Folklore in Lifelong Learning and Its Psychological Aspects
}

\author{
Serkhan Khaveri ${ }^{1}$ \\ Sefa Garayev ${ }^{2}$ \\ Hikmet Guliyev ${ }^{3}$ \\ ${ }^{1}$ Assos. Prof., ANAS Institute of Folklore, Azerbaijan \\ Email: sarxan.xaveri@mail.ru \\ ${ }^{2}$ Assos. Prof., ANAS Institute of Folklore, Azerbaijan \\ Email: safaqara@mail.ru \\ ${ }^{3}$ Assos. Prof., ANAS Institute of Folklore, Azerbaijan \\ Email: quliyevh@mail.ru
}

Article History: Received: 10 November 2020; Revised 12 January 2021; Accepted: 27 January 2021; Published online: 5 April 2021

\begin{abstract}
One of the most important conditions for the education to be targeted to the requirements of modern times, as well as to be suitable for social orders, is determining the effective training technologies. Many socio-cultural institutions, including the training models of the traditional-cultural institutions and the traditional models of knowledge transfer can be urgent and effective in determining the effective learning technologies. In this sense, folklore has a great potential of use in the application of modern educational technologies with its own functional capabilities that played an important role during many centuries in the interaction of some individuals with one another, in the socialization of people and in the self-formation of society. It is known that in the traditional-cultural environment there were institutional aspects and structures of knowledge transfer. Before the appearance of the written language in the oral communication level the information, i.e. the gained experience and knowledge were passed with the empiric models from generation to generation by old people, wise elders who were the institutional aspects of the traditional culture.

The training technologies of the traditional culture have the following peculiarities:

1. Unlike the religious training technologies, it is not dogmatic, it has a democratic nature.

2. Taking into consideration the vital situations it has an operative adaptation character.

3. It has a character of getting and transferring the knowledge empirically.

4. It has the ability of taking into consideration the individual abilities and character in the process of incessant learning and teaching.

The appearance of the Internet which is considered the "apogee" of communication has caused the formation of new transformations of traditional folk culture, virtual folklore samples as in all other spheres. Of course, in modern times at the stage when the digital resources are growing, the methods and means of getting, transferring and mastering knowledge, as a whole, the formation of education has completely changed. That is why, we consider that it is possible to use the opportunities of folklore the potential of virtual folklore and digital folklore resources, in the of lifelong education and innovative educational concepts, in getting and teaching of knowledge. Because the folklore resources have unique opportunities in formation of socio-psychological essence of personality. There is a great need for the individual to adopt the folklore of this group to freely enter and become a member of various social groups without experiencing psychological complex and tension in all spheres of
\end{abstract}


society. In this sense, one of the goals of modern education is to aim the growing new generations to promote stereotypes that are in harmony with human values and to free them from non-humanist and local stereotypes.

\section{Keywords}

Virtual folklore, functional and psychological aspects, lifelong education

\section{Introduction}

The establishment of the knowledge society in the modern conditions depends directly on the being trained of the highly qualified human race. In this case the education in modern societies is considered the social institution with the strategic importance. One of the most important conditions for the education to be targeted to the requirements of modern times, as well as to be suitable for social orders, is determining the effective training technologies and to get the lifelong learning. With the condition of the life education many socio-cultural institutions, including the training models of the traditional-cultural institutions and the traditional models of knowledge transfer can be urgent and effective in determining the effective learning technologies. In this sense, folklore has a great potential of use in the application of modern educational technologies with its own functional capabilities that played an important role during many centuries in the interaction of some individuals with one another, in the socialization of people and in the self-formation of society.

It is known that the need for any knowledge and experience on various issues acts as a natural condition of life activity of the individual or society taken separately. The transfer of knowledge and experience gained by people at all stages of social progress from the generation to generation has become an important condition of the sustainable development of mankind. During ancient times in the traditional societies in the absence of writing the only means of transmission of knowledge and experience was folklore. The protection of the collected knowledge and experience in time and space was possible only through folklore and its effective methods. That is why from the functional point of view, among the numerous pragmatic functions of folklore its training function occupies an important place. Among the folklore examples of any nation the invitation to knowledge and investigation, propaganda and encourage, culturing knowledge, making the persons sacred who are carriers of knowledge and experience take an important place (Poyraz \& Titrek, 2013: 115-131). For example, in the epos "The Book of Dede Gorgud" the sacred status of the character Dede Gorgud is arranged with the following arguments: "Oghuzun ol kishisi tamam bilijisi idi" ("He was wise in Oghuz") (Hajiyev, 2004: 19). Or let us look through the following proverbs:

"Not knowing is not a shame, not asking is a shame", "Better to do well than to say well” (Zeynalli, 2012: 82).

\section{Method}

In the article the usage of the functional capabilities of virtual folklore in lifelong learning and in order to determine its psychological aspects the modern educational processes have been compared with the transfer of knowledge and experience in traditional culture, the 
prospects of applying the potential opportunities of folk pedagogy to lifelong learning have been chosen as the main principle. In the research process the cultural, technological, psychoanalytic, and social psychological approaches have been used.

\section{Main text (findings)}

It is known that that there were institutional aspects and structures of knowledge transfer in the traditional cultural environment. Before the formation of the writing at the stage of oral communication the information - the gained experience and knowledge were transmitted with the empiric models specially from the generation to generation by old people, wise elders, grandfathers and grandmothers who were institutional aspects of the traditional culture. The art of Ashug that widely spread among the Turkic peoples was the embodiment of the transmission of oral knowledge as a cultural institutional structure, that is to say in modern terms, the circulation of the training in the chain model of "teacher-student" ("master-apprentice").

\section{The functional training technologies of the traditional culture}

The training technologies of the traditional culture have the following peculiarities:

1. Unlike the religious training technologies they are not dogmatic, they have a democratic nature.

Although the transmission of knowledge and experience in the oral cultural environment has the stable models based on the traditional nature, it has the ability of adapting the skills and abilities of individuals. For example, though the master- apprentice relations are chosen as the target of teaching folkloric units to the apprentices, the special attention is paid to the identification of individual parameters and specific characteristics of learners. It is no coincidence that being performers and creative the ashugs are divided into two groups. Looking through the relations of masters and apprentices in the cultural system, it becomes clear that, in fact, this classification is carried out according to the individual abilities of the learning apprentices. In fact, the proverbs and sayings such as "It takes all sort to make a world", "You should never take anything to a place where there is already plenty of it" (Zeynalli, 2012: 57), etc. point to the individuality. Thus, this reality arising from the logic and dictation of relations in real social life was determined in folklore with the paremical units.

\section{Paying attention to the vital situations it has the property of operative adaptation.}

As folklore is based on the real and virtual communication of interpersonal and intergroups processes, according to the suitable life situations, it has a feature of flexible adaptation. The folkloric manifestation which is regarded as the text multi-variance due to the philological point, in fact, is an indicator of the flexible adaptation of folklore under the influence of the social life circumstances. This aspect has a very important role in the transfer of knowledge and experience in the traditional culture in order to make norm in the context of a particular group. As it is known, there are definite differences such as age, gender, profession, social relation, religion, ethnicity, etc. among individuals and groups that pass and accept knowledge in the folklore process. In such situations these different aspects act as barriers of the effective transfer of knowledge and experience. The elimination of these 
barriers in the folkloristic training technologies is possible only through the operative adaptation according to the vital situations. For example, the main function of children's games is the practical perception of the orders and rules of reality. But from the observations it is seen that the variants of the same games for teenagers serve to formalize their imagination of sexual differentiation.

3. It has the property of getting and transferring knowledge (lore) by the empirical way.

The different social groups have not the established program for passing their folklore. In different situations of life, when it is needed, certain folklore units are passed from generation to generation by repetition. But the part of folklore related to professions and arts is realized on the basis of visual, obvious and performing qualities of the teaching and learning subjects.

\section{It has the feature of continuous learning and teaching.}

The lifelong education, which is one of the main educational disciplines of modern times, is closely related with the continuous transmission character of knowledge and experience belonging to the nature of folklore. Thus, the concept of accepting and transferring of knowledge in the continuous form also exists in the culture. As it is mentioned in one of Azerbaijani proverbs "It is never too late to learn" is also one of the invitations to the lifelong education.

\section{View to the conception of lifelong learning from folklore}

In modern times telling "the lifelong learning" all types of lifelong learning (Decree of the Cabinet of Ministers of Azerbaijan Republic about to affirm "National Qualification Frame on the lifelong learning of Azerbaijan Republic) such as "knowledge, skills, competence or qualifications resulting in improvement of lifelong learning" is meant. The basic competences on lifelong learning reflect the multifunctional system that "unites each individual with such characteristics as knowledge, skills, value, approach, ideas and characteristic necessary for individual development, integration into society and engagement. These competences must be acquired in the comprehensive manner at the end of the compulsory education or training in all subjects taught to the educator and play the main role for future education as a part of the lifelong learning process" (Decree of the Cabinet of Ministers of Azerbaijan Republic about to affirm "National Qualification Frame on the lifelong learning of Azerbaijan Republic).

If we approach folklore from the lifelong learning paradigm, which is the main paradigm of modern education, we can see that training of the necessary competences for the different social groups and different individuals is one of the main pragmatic functions of folklore. Mastering the necessary knowledge and experience in various spheres of social life to people through the effective methods at all stages of life forms the analogy with the need of competences in the present conditions. Changing the age groups the human's social status in the society changes in the parallel form. But each new social status requires the new knowledge and skills, new competences than the previous ones. This process attains actuality continually. In this sense, the folkloric communication is a lifelong exchange of knowledge and experience in all cases and it has the ability to cover the entire social circle not depending on the age group. 
A look at the concept of lifelong learning from the folklore aspect requires looking through the age difference among the social groups that learn and teach at the same time. From this point of view, it would be better to get acquainted with the conceptual view by American cultural anthropologist Margaret Mead which is widely used in cultural and anthropological studies on the transfer of experience from generation to generation in culture. Margaret Mead divides cultures into three groups in terms of transfer of experience:

1. Postfigurative culture - the knowledge and practice are adopted from the old generation;

2. Configurative culture - the knowledge and practice are adopted from the old generation, as well as from the same age;

3. Prefigurative culture - the knowledge and practice are also adopted from the juniors (Маргарет)

The scientist makes such a conclusion that the orientation of the social progress of humanity is directed to the past in the first stage, but in the second stage it is directed to the present and in the third stage it is directed to the future. The author mentions that postfigurativeness is a feature directly belonging to the traditional societies. (Маргарет).

As it is mentioned in above not depending on any historical stage the process of the process of folklorization is carried out with the transfer of widely gained experience from generation to generation. The tradition realizes the relationship between the past and the future through the mechanisms of transfer of experience between the older generation and the younger generation. Our aim is to draw attention to the fact that the model of the dissemination of experience in the culture defined through its categorical concepts expresses exactly the folklorization itself. It is no coincidence that there is a rich experience of the usage of folk pedagogy in the educational process in most peoples of the world (Marina and Žana, 2016: 41-52).

So, looking at folklore from the lifelong education paradigm it becomes clear that folklore, which has been adopted as understanding and expressing the world from a young age, plays an important role as a social-cultural mechanism in the mastering and exchange of new knowledge and experiences in next stages. If we consider that one of the main goals of lifelong learning is to gain relevant knowledge and skills, competences and abilities in the updated social conditions, then it is possible to use folklore in the teaching methods of lifelong learning. Because the folklore performance based on the mutual communication and attitude of teachers and learners is one of the most important conditions for mastering knowledge (Morgan-Fleming, 1999: 285).

\section{The role of digital folklore resources in lifelong learning paradigm}

After the second half of the $20^{\text {th }}$ century, the rapid development of ICT (Informationcommunication technologies), the emergence of the Internet which is considered the "apogee" of communication (Krawczyk-Wasilewska, 2016: 23) has led to the formation of new transformations of traditional folk culture, examples of virtual folklore as in all other spheres. Of course, in modern times when the digital resources are growing, the methods and means of getting, transferring and mastering knowledge, as a whole, the nature of education has changed completely. Especially in the context of the wide spread of digital 
communication, the emergence of the virtual world, the new generation of modern man is one of the problems that take place in the programs of a number of international organizations around the world. From this point of view, we consider that it is possible to use the opportunities of folklore, in particular, the potential of virtual folklore, digital folklore resources, in the implementation of modern training methods and innovative educational concepts in the getting and teaching of knowledge. In the modern era of quickening the processes of globalization and transformation the man is a member of virtual social groups along with a network of real social relations. In particular, the emergence of digital means of communication and the formation of mobile platforms of social networks have led people to spend almost the entire day online. From getting the information, news till the most fundamental scientific researches, or from the smallest domestic affairs to the most global and strategic issues, the activity is directly connected with the Internet. In general, the fact that communication is based on virtual platforms has led to the emergence of a new space for spiritual culture - folklore activity as in all spheres. "The communities of users coming together in virtual interaction platforms under the guidance of motivations such as proximity, need for socialization, regular and instant interaction, the common interests and experiences, contain many qualities of a folkloric group and new, rich and original folkloric groups that are not equivalent in real life and the ability to produce content" (Gülüm, 2018: 132). From the ancient times to the present day, folklore as the main means of differentiation of human reality in the form of conception and expression, social organization and formation, division into groups and ideologies in today's conditions - the rapid expansion of the Internet, the domination of virtual communication, etc. equally, new forms and formats are emerging in content and themes.

In such circumstances, it is very urgent and important to use new opportunities and tools for the education of the person, the sectors related to his or her most diverse fields of activity, especially the teaching of knowledge and skills, skills and abilities. From this point of view, it is difficult to imagine the concept of lifelong learning, the new paradigm of modern education, beyond virtual and digital resources, as well as Internet folklore and digital culture. To tell truth, it is possible to use a wide range of virtual folklore resources in the application of the lifelong learning concept. It is possible to make effective use of the virtual folklore resources available in social networks and forums in realizing the implementation of knowledge and information provision of subjects participating in continuous education or lifelong learning process with humanitarian and social tendentious knowledge. Thus, unlike the traditional folklore facts, the examples appeared in the virtual environment are seen on the base of the non-conservative, free attitude to tradition. The virtual folklore samples offer the new alternatives to traditional, normalized and stereotyped approaches and views. The parodical attitude to images and values protected by the national stereotypes creates emotional sensitivity and it creates the favorable conditions for transmission or reception of the certain information. In other words, the parodical attitude to the stereotypes at the same time creates the effective psychological situation for the transfer of knowledge. If we apply to the Turkish experience, we shall see that "The Examination of License Replacing in Internet (LYS) and Public Personal Examination (KPSS) followed by students preparing practical knowledge about the topics of Turkish literature, lesson notes sharing pages are available. In some of these sites the information about the literary 
personalities, their works and the knowledge about the classical Turkish literature are usually given through "gaps" or in a humorous language. The parodical profiles made up of fake user profiles created on various websites for famous poets and writers are also one of the examples that represent social media humor. In the profiles created for poets of classical Turkish literature and Turkish folk literature give information about their lives, literary personalities and works in a humorous style in the form of ridicule and the poem examples by the poets are shared" (Yilmaz and Berk, 2016: 177-189). As it is seen, the certain profiles (true and false) have been created by the persons preparing for various types of exams on Turkish-speaking sites and forums, through these profiles the electronic resources on various topics (from the current, daily cares to the most different fields of science) are created. A certain part of those electronic resources are folkloric examples in comic or parodical styles. In fact, those examples, which show themselves as a virtual environment of socio-cultural processes of modern times, as well as the emergence of folklore on the Internet, are integral parts of the virtual world of a modern man. Each Internet user or member of the social network is its creator, as well as its user within those processes. In other words, each of us is the founders and users of the virtual world, the virtual folklore which is part of it. In this regard, we can say that folklore resources created in social networks through fake profiles or fake user accounts ("fake profile" and "fake user account") can be used for various purposes. It is possible to apply the same experience in lifelong learning, to use the electronic resources available on the Internet on the most diverse topics and content.

\section{The psychological aspects of the problem}

Folklore resources have unique opportunities in formation of socio-psychological essence of personality. There is a great need for the individual to adopt the folklore of this group in order to freely enter and become a member of the various social groups without experiencing psychological complex and tension in all spheres of society. In this sense, one of the goals of modern education is the promotion of stereotypes (Hamer, 2000: 49) and to direct to freedom from the non-humankind and local stereotypes. The investigations prove that if the virtual folklore examples are used in the modern educational technologies effectively, it can greatly help people to move away from the local psychological stereotypes, to adopt universal values through education, and at the same time to form as a leader without experiencing widespread cultural shock and acculturation stress.

The man simultaneously operates in folklore groups with different levels. As the social responsibility of individuals expands, along with the quantity of their participation in separate groups, the serious changes are revealed in their quality. The social groups with their specific shades have ideas and concepts that support their ideologies, which play a decisive role in the views of the people of that group on life, the establishment of relations with other members of society, the determination of their reactions to various social events. The different social groups have different folkloric units that support their idioculture (Fine, 2005; 69; Fine, 1979: 734), which both define and promote the emotional-expressive nature of these groups. In addition to increasing the number of groups in the Internet environment, which is a new stage of human socialization, the differences in their goals are constantly increasing. In the formation of the personality of the learner studying in such conditions, more complex factors 
arise, which formalize the "life training" of subjects in this or another degree, and without taking into account these factors, it is a very difficult task to achieve its goal. The complexity of the essence of education in all spheres of life requires a flexible, dynamic and sensitive attitude to it. It is no coincidence that although it is possible to identify the factors that affect the formation of subjects in the traditional culture, which belong to a certain territory and to struggle with the factors that affect them negatively, the emergence of global virtual environments for different purposes and the large number of individual negative effects are focused on the problem of personality formation. In the environment where such complex virtual environments affect the formation of human personality, the role of folklore in lifelong learning conception cannot be neglected.

\section{Results}

Thus, with the usage of the functional capabilities of virtual folklore in lifelong learning and its research on psychological aspects the following conclusions were drawn:

1.Many socio-cultural institutions, including traditional educational methods of cultural institutions (folklore), traditional models of the transfer of knowledge are active and effective in determining effective training technologies on the condition of lifelong learning, they have a great potential of use in the application of modern training technologies with their functional capabilities.

2.The following characteristics of the training technologies of the traditional culture have been identified:

- Unlike the religious training technologies, it is not dogmatic, it has a democratic nature;

- Paying attention to the vital situations it has the feature of operative adaptation;

- It has the property of getting and transferring knowledge by the empirical way.

- It has the feature of continuous learning and teaching.

3.Looking at folklore from the lifelong education paradigm it becomes clear that folklore, which has been adopted as understanding and expressing the world from a young age, plays an important role as a social-cultural mechanism in the mastering and exchange of new knowledge and experiences in next stages.

4.Unlike the traditional folklore facts, the examples appeared in the virtual environment are seen on the base of the non-conservative, free attitude to tradition, it is possible to make effective use of the virtual folklore resources available in social networks and forums in realizing the implementation of knowledge and information provision of subjects participating in continuous education or lifelong learning process with humanitarian and social tendentious knowledge.

5.There is a great need for the individual to adopt the folklore of this group in order to freely enter and become a member of the various social groups without experiencing psychological complex and tension in all spheres of society.

6. If the virtual folklore examples are used in the modern educational technologies effectively, it can greatly help people to move away from the local psychological stereotypes, to adopt universal values through education, and at the same time to form as a leader without experiencing widespread cultural shock and acculturation stress. 


\section{References}

1. Fine, Gary Alan (2005). In the company of men: female accommodation and the folk culture of male groups. In Manly Traditions: The Folk Roots of American Masculinities, Edited by Simon J. Bronner, 62-76. Indiana University Press.

2. Fine, Gary Alan (1979). Small Group and Culture Creation: The İdioculture of League Baseball Teams. American Sociological Review, 44: 733-745.

3. Gülüm, Erol (2018). Dijital iletişim teknolojileri aracılı bir folklorik denyim alanı olarak sanal ortam. Milli folklor 119, s. 127-139

4. Hajiyev, T (2004). Kitabi-Dədə Qorqud. Osil və sadələşdirilmiş mətnlər. Bakı: Öndər, 376 s.

5. Hamer, Lynne (2000) "Folklore in Schools and Multicultural Education: Toward Institutionalizing Noninstitutional Knowledge." The Journal of American Folklore, vol. 113, no. 447, pp. 44-69.

6. Krawczyk-Wasilewska, Violetta (2016). Folklore in the Digital Age: Collected Essays. Foreword by Andy Ross. Lodz, Lodz University Press.

7. Marina Ilić , Žana Bojović. (2016) Teachers' Folk Pedagogies. Journal of Arts \& Humanities. Volume 05, Issue 09, 41-52

8. Маргарет, Мид: постфигуративная, кофигуративная и префигуративная культуры. https://studme.org/128004154844/kulturologiya/mid_postfigurativnaya kofigurativnaya_prefi gurativnaya_kultury (14.07.2019)

9. Morgan-Fleming, B. (1999). Teaching as Performance: Connections between Folklore and Education. Curriculum Inquiry, 29 (3), 273-291.

10. Decree of the Cabinet of Ministers of Azerbaijan Republic about to affirm "National Qualification Frame on the lifelong learning of Azerbaijan Republic. "Azərbaycan Respublikasının ömürboyu təhsil üzrə Milli Kvalifikasiyalar Çərçivəsi”nin təsdiq edilməsi barədə Azərbaycan Respublikasi Nazirlər Kabinetinin Qərarı http://eqanun.az/framework/39622

11. Poyraz, Hande \& Titrek, Osman (2013). Development of Lifelong Learning in Turkey. Abant İzzet Baysal University Education Faculty Journal. 13. pp. 115-131

12. Yilmaz, Gökçehan, Yilmaz, Berk (2016). Sosyal Medyada "Caps"ler ve Parodi Hesaplarla Türk Edebiyatı: Klasik Türk Edebiyatı ve Türk Halk Edebiyatı Örneği. Uluslararası genc akademisyenler kültür kongresi. Bildiriler kitabı. İzmir s. 177-189.

13. Zeynallı, Hənəfi (2012). Azərbaycan atalar sözü. Bakı: Elm və təhsil, 174 s. 